LSE 'Europe in Question’ Discussion Paper Series

\title{
A New Concept of European
}

\section{Federalism}

Bruno S. Frey

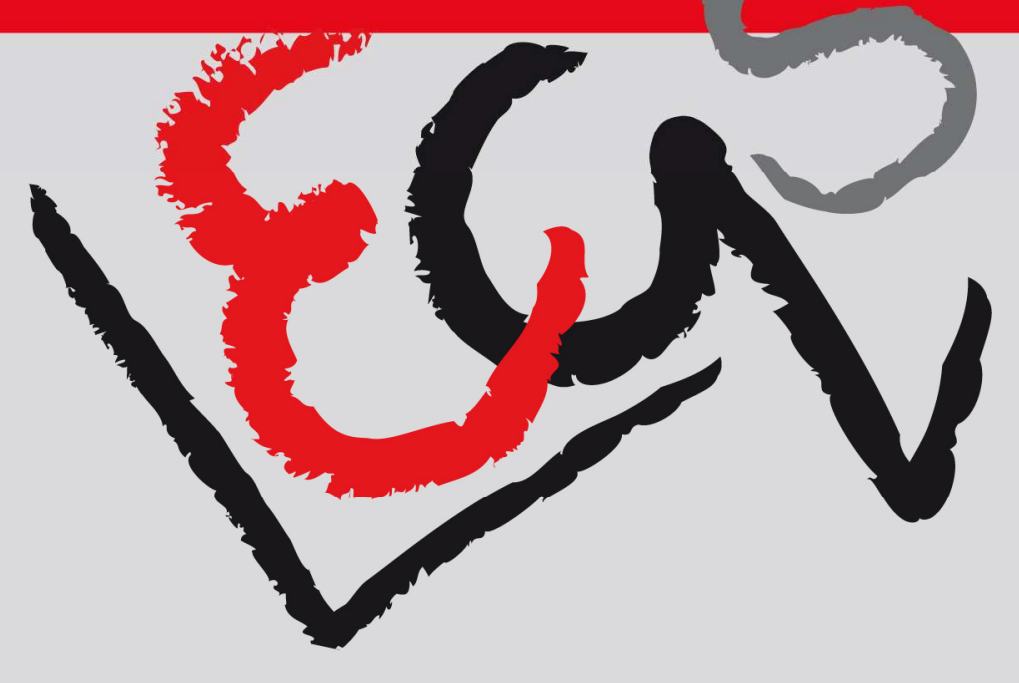




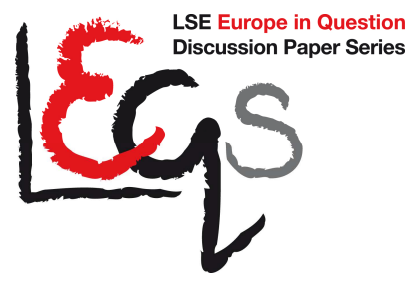

\section{Editorial Board}

Dr. Joan Costa-i-Font

Dr. Vassilis Monastiriotis

Dr. Jonathan White

Ms. Katjana Gattermann

All views expressed in this paper are those of the author and do not necessarily represent the views of the editors or the LSE.

(C) Bruno S. Frey 


\title{
A New Concept of European
}

\section{Federalism}

\author{
Bruno S. Frey*
}

\begin{abstract}
By opening markets the European union has been also an economic success. However, with respect to political organization the European Union is far less accomplished. The misguided concept of a successful Europe consists in mistaking integration for harmonization and homogenization. But the essence of Europe is its diversity. No steps have been taken to actively institutionalize competition between governmental units at all levels. The welfare of European citizens could be improved by promoting competition between new jurisdictions. A new type of federalism based on Functional, Overlapping Competing Jurisdictions FOCJ is here proposed. FOCJ form a federal system of governments emerging from below as a response to citizens' preferences. The lowest political units (communes) must be given the freedom to engage in forming FOCJ and must have the right to levy taxes to finance the public services they provide.
\end{abstract}

Keywords: federalism, constitutional economics, public choice, monopoly on territory

JEL classification codes: H11, H4, H5

\footnotetext{
* Institute for Empirical Research in Economics, University of Zurich

Correspondence:

Winterthurerstrasse 30

8006 Zürich, Switzerland

Email: bsfrey@iew.uzh.ch
} 


\section{Table of Contents}

Abstract

1. Integration as Harmonization - and its Alternative 1

2. Relationships between Government and Territory 3

2.1. Several Governments on the Same Territory 3

2.2. Governments Without Territory 4

3. Federalism and Political Competition 5

4. Competing Jurisdictions 9

4.1. Functions 9

4.2. Overlaps 10

4.3. Competition 10

4.4. Jurisdictions 11

5. Strengths of FOCJ 12

6. Claimed Weaknesses of FOCJ 13

7. Contemporary Examples of FOCJ 15

8. Competing Proposals 16

9. Conclusion: FOCJ and the European Union 19

References 


\section{A New Concept of European}

\section{Federalism}

\section{Integration as Harmonization - and its Alternative}

By opening markets the European integration has also become an economic success. The assurance of the four freedoms of liberal trade, with respect to goods and services, and capital and labor, have been achieved to a considerable degree. The European Union can be proud to have established a market covering almost the whole of Western Europe.

With respect to political organization, however, the European Union is far less successful, if not an outright failure. A mistaken concept of what Europe should be, has increasingly taken over and the unification process has taken a wrong turn. The erroneous concept of a unified Europe consists in identifying integration with harmonization, which to a large extent means homogenization. But the essence of Europe is its diversity. The strength of Europe is its wide range of different ideas, cultures, institutions and policies. These differences have spurred its great achievements in the arts, sciences, and the way of living. A homogenized Europe loses its raison d'être, and will lose its economic and political importance. In contrast to the economic sphere, an open and competitive market for politics has been suppressed, rather than supported. No steps have been taken to actively institutionalize competition between governmental units at all levels. Rather, the European treaties and institutions have increasingly restricted competition between governments.

This paper argues that the welfare of European citizens could be improved substantially by promoting competition between newly emerging jurisdictions organized according to functions instead of territories. A new type of federalism based on Functional, Overlapping Competing Jurisdictions is proposed. Hence, their acronym 


\section{A New Concept of European Federalism}

FOCJ (one such jurisdiction will be called FOCUS) will be used. This system of democratic decentralized jurisdictions drastically differs from the system that governs the European Union today. FOCJ form a federal system of governments emerging from below as a response to citizens' preferences. The European Constitution proposed here must give the lowest political units (communes) the freedom to engage in forming FOCJ. The citizens must be given the right to establish FOCJ through popular referenda. The FOCJ must have the right to levy taxes to finance the public services they provide.

The idea developed here is based on four basic elements: a future Europe has to be peaceful, democratic, diverse, and productive. Therefore, this proposal emphasizes the importance of the role of citizens in the political process. The proposal suggests a decentralization of the political process and its reduction to the functionally most appropriate level. It thus seeks to redress the two well-known and often lamented shortcomings of the European Union: its democracy deficit and its decentralization deficit. The subsidiarity principle enshrined in the Maastricht Treaty does not truly serve to mitigate the "decentralization deficit". It remains ineffective as long as the regions of Europe financially depend on Brussels and on the central governments of their nations. Successful political decentralization requires that the lower levels of government have the power to tax. Such local fiscal responsibility induces the citizens to balance the benefits and costs of public expenditure and, thus, motivates politicians in lower-level governmental units to use the scarce resources for the benefit of the citizens.

The vision entertained here may seem quite radical, but it is not outlandish. The proposal does not require the dismantling of the national states forming the European Union. Though the nationalism entailed in the concept of a nation has brought enormous harm to Europe in the $20^{\text {th }}$ century, it is still exceedingly well established. The flexible political competitors suggested here cater to the effective provision of services to the citizens. As a consequence, traditional nation states are forced to substantiate their right of existence by caring efficiently for those needs and demands of the population that they are best able to provide. A major advantage of 
the proposal is that it can be introduced in marginal steps.

Section II discusses the relationships between governments and territory. Sections III and IV develop the concept of FOCJ and puts it into theoretical perspective. The following two sections discuss the strength and claimed weaknesses of the concept. Section VII provides contemporary examples of FOCJ. The following Section analyzes competing proposals for a future European federalism. The last Section IX concludes by discussing the possible role of FOCJ in the European Union.

\section{Relationships between Government and Territory}

A government or state has its corresponding territory. This is normally taken for granted. The relationship is one to one: Each government controls a particular territory, and each territory belongs to a particular government. Moreover, the relationship is clearly defined. There is no uncertainty which government rules over which particular territory, and each territory is unequivocally assigned to some government.

Yet there are important instances in which this identification of government with territory does not hold:

\subsection{Several Governments on the Same Territory}

A classic case would be that several governments claim the same territory. Sometimes borders are ill-defined, sometimes the rights to a territory are disputed, and sometimes have been for centuries. This has been the cause for innumerable wars in the history of mankind. An important example that can lead several "governments" or "nations" to claim authority over the same territory is a claim by ethnic groups. The past conflicts in ex-Yugoslavia and many current conflicts in Africa and in many other parts of the world are examples of this. According to Singer 


\section{A New Concept of European Federalism}

and Small [1982], in the period 1916-1939, no less than 80 percent of the wars occurring in (what is now called) the Third World were due to ethnic conflicts, which lead to civil strife. After 1945, this proportion rose to 90 percent. Overall, no less than 75 percent of international wars are due to ethnic groups claiming authority over a territory.

Federal states, in contrast, are a propitious institution allowing several governments to act in the same territory: the central state, the provinces, states or Bundesländer, and the communes.

\subsection{Governments Without Territory}

There are many different quasi-governmental organizations (QANGOs), which perform similar, if not identical, functions as states do. Examples for this are international organizations, such as the United Nations or the International Court of Justice in Den Haag. They consist of member countries, but they do not have any monopoly power over a territory. The number and importance of such "virtual" governments has increased considerably. At least 350 intergovernmental international organizations exist with far more than 100'000 employees. A more extensive definition, based on the Yearbook of International Organizations lists more than 1000 intergovernmental units (see e.g. Frey 1997).

Religious organizations, of which the Catholic Church is a good example, represent another case of virtual governments. The Catholic Church has a monopoly over a tiny territory in Rome, but its importance derives from a completely different source, namely the allegiance of its members. To some extent it performs similar activities to regular governments (e.g. it pursues a foreign policy) and it even raises taxes. Perhaps more relevant today are sports organizations, some of which have substantial resources available. One example is FIFA, the international football association. They also undertake some government-like activities (e.g. they impose rules on their members, they have a foreign policy, undertake development aid etc.). 
The same applies to cultural associations and international activist groups (such as Greenpeace), which are not connected to a territory.

Profit-making global firms are the most important virtual governments without territory. The more traditional ones still own plants located in specific countries, but the digital revolution has created a rapidly increasing number of knowledge firms in the New Economy. Their only capital are human resources and ideas, and they are not attached to any territory at all. Quite often, the turnover of such companies is compared to the size of the public sectors of territorial states. Only a few large countries can match the size of the largest international companies. Such firms perform governmental functions in the sense that they influence the daily lives of their members at least as strongly as states do (e.g. they impose what language is to be spoken, and which rules are to be followed), and they negotiate on an equal footing with national states.

International organizations, churches and global firms do not meet the traditional legal definitions of a "government". These units are indeed not identical to governments. But it should also be kept in mind that the traditional definitions of government are based on the simplistic notion that it is the nature of governments to have a territorial monopoly. But the purpose of this discussion is precisely to question this assumption from a social science and economic point of view. Adopting this radically different viewpoint, it becomes clear that there are indeed multiple governments on any given territory, as well as governments without territory. Governments need not have a territorial monopoly.

\section{Federalism and Political Competition}

The basic idea of federalism is that the preferences of individuals can better be met by decentralizing government activity. The goods and services offered by the government can more narrowly be geared to these demands because they differ with respect to: 
- geographical and physical characteristics, e.g. between mountainous regions and planes; or between rural areas and cities;

- ethnicity, culture and traditions;

- economic structure, e.g. with respect to the amount of agricultural and industrial production and services; and

- social structure, e.g. with respect to income distribution, the number of young families with children and retired persons.

These differences obviously lead to varying demands for public activity, e.g. with respect to the expenditures desired for educational or social services. In a purely technocratic concept of politics, a centralized government can meet such spatially varied demands. However, this utterly disregards human behavior and essentially assumes the existence of an omniscient and benevolent planner. However, long ago this notion was rejected theoretically by Smith (1776) for economics and for society as a whole by von Hayek [1960; 1978]. In the political sphere, decentralization has clear informational advantages, because local politicians are more aware of the local needs and constraints. Even more important are the incentives motivating local political decision-makers to cater to the wishes of the local population who elects them.

The Economic Theory of Federalism (see e.g. Oates [1972]; [1977], [1999]; Bird [1993]; Inman and Rubinfeld [1997]) has focused on four important theoretical elements:

Fiscal Equivalence (Olson [1969]; Oates [1972]; Olson [1986]). Each jurisdiction should extend over an area in such a way that the recipients of benefits and taxpayers correspond as closely as possible. Spatial external effects - positive spillovers where non-payers benefit from public services, and negative spillovers where outsiders are burdened with costs - are therewith avoided. The various public activities are to be attributed to the most appropriate government level.

Clubs (Buchanan [1965]). These are institutions offering public goods only - i.e. goods from whose benefits nobody can be excluded - to its members. The 
optimal size of a club is reached when the marginal utility received corresponds to the marginal cost induced by an additional member. A club thus has a limited membership, and only those persons are admitted who are prepared to carry the marginal cost they impose.

Voting by Foot (Tiebout [1956]). Competition between jurisdictions is brought about by citizens' mobility. Public jurisdictions can be looked at as enterprises offering local services in return for taxes. The citizens migrate to those jurisdictions that have the most favorable relationship between services and tax prices. The competition created forces the jurisdictions to take the citizens' wishes into account and to supply services at the lowest possible cost. The same holds for the location decision of firms.

Exit and Voice (Hirschman [1970]; [1993]). In addition to the option to choose among the supply of various jurisdictions, citizens may also participate in the political decisions of the jurisdictions they belong to, either by voting in elections or referenda. Moreover, they may make themselves heard through protests, demonstrations, strikes and uprisings. Initially, exit and voice were seen as substitutes. A citizen who chooses to leave a jurisdiction has little incentive to go through the trouble of protesting. However, under particular circumstances the relationship may be complementary. Thus, when the government of the GDR had to grant exit permits to its citizens (or: had to allow its citizens to leave) (via Hungary to the West), this was generally interpreted as a sign of weakness of the Communist regime. As a consequence, protests and demonstrations were perceived as less dangerous and more promising, and therefore grew into a mass movement (the so-called "Monday Demonstrations"), eventually forcing the resignation of the regime.

For federalism to work in a satisfactory way, two crucial conditions need to be met:

(a) The sub-units must have the power to tax citizens for the services they perform. This forces sub-units to balance the benefits and costs of government activities. At the same time, this gives the sub-units a certain 


\section{A New Concept of European Federalism}

degree of independence from the central government. However, this requirement is not met in most "federations". As a consequence, local politicians engage in widespread rent seeking activities with the central administration. To obtain funds they have to please the political decision makers at the centre. Once granted, they have few incentives not to spend them in their entirety, as such funds have the character of a "free good". The local politicians' rent seeking activities also encompass subsidies to cover budget deficits. Such an institutional landscape fosters fiscal irresponsibility at the local level. As this "irresponsibility" is a direct consequence of the high degree of centralization, it does not occur when local politicians have the competence to balance revenues and expenditures in their own jurisdiction. If it turns out that they are incapable of doing so, the citizens will throw them out of office.

(b) To guarantee a well-functioning federalism local politicians must be elected by the citizens of their jurisdictions, and not by a larger electorate, let alone be appointed by the central government. This requirement aligns the politicians' incentives with the wishes of the local population.

Most currently existing federal governments do not meet these two requirements, or do so only to a small degree. For that reason, the proposal for a new type of federalism is advanced, which is a combination of the four aspects of federalism discussed above: (1) it meets the condition of "fiscal equivalence" by suggesting a network of multiple and overlapping governmental units; (2) it is based on welldefined members and boundaries according to the public functions to be performed, and thus is comparable to a "club"; (3) it is competitive by allowing entry and exit of members according to the "voting by foot" mechanism; and (4) it adds political competition via elections and referenda and thus includes institutions favoring "voice". 


\section{Competing Jurisdictions}

The federal units here proposed are called "FOCJ" according to the acronym of its essential characteristics:

- Functional (F): the new political units extend over variable areas, corresponding to the tasks or functions to be fulfilled;

- Overlapping (O): in line with the many different tasks (functions), there are corresponding governmental units extending over different geographical areas, which necessarily intersect;

- Competing (C): individuals and/or communities may choose to which governmental unit they want to belong, and they have political rights to express their preferences directly via initiatives and referenda;

- Jurisdictions (J): the units established are governmental; they have enforcement power and can, in particular, levy taxes.

FOCJ form a governmental system, which in an essential aspect is quite different from the one suggested in the economic theory of federalism. This theory analyses the behavior of given political units at the different levels of government, while FOCJ emerge in response to the 'geography of problems'.

The four elements of FOCJ are now discussed in more detail.

\subsection{Functions}

Any particular public service that benefits a certain geographical area should be financed through the people living in that area, i.e. there should be no spillovers. The different governmental units can cater to a population's preferences and accommodate differences, more precisely, to the citizenry's demands. To minimize cost, these units have to exploit economies of scale in production. As the latter may 


\section{A New Concept of European Federalism}

strongly differ between functions (e.g., between schools, police, hospitals, power plants and defense) there is an additional reason for uni-functional (or fewfunctional) governmental units of different sizes. This endogeneity of the extension of the governmental units constitutes an essential part of FOCJ.

\subsection{Overlaps}

FOCJ may overlap in two respects: (i) FOCJ performing different functions may intersect; (ii) two or more FOCJ offering the same services may geographically intersect (e.g., a multitude of school FOCJ may exist in one geographical area). An individual or a political community usually belongs to a variety of different FOCJ at the same time. FOCJ need not be physically contiguous, and they need not have a monopoly over a certain area of land. Thus, this concept completely differs from archaic nationalism, which often leads to land disputes. It also breaks with the concept of federalist theory that units at the same level may not overlap.

\subsection{Competition}

The heads of FOCJ are induced to conform closely to their members' preferences by means of two mechanisms: while the individuals' and communities' possibilities to exit mimics market competition, their right to vote establishes political competition. It should be noted that migration is only one means of exit; often, membership in a particular FOCUS (this is the singular of FOCJ) can be discontinued without changing one's residence. Exit is not limited to individuals or firms; also political communities as a whole, or parts thereof exercise this option. Moreover, exit may be total or only partial. In the latter case, an individual or community only participates in a restricted set of FOCUS activities.

In order for FOCJ to establish competition between governments, exit should be restrained as little as possible. In contrast, entry need not necessarily be free. As for 
individuals entering Buchanan-type clubs, jurisdictions and individuals may be asked a price if they want to join a particular FOCUS and benefit from its public goods. The existing members of the particular FOCUS have to democratically decide whether a new member pays an adequate entry price and is thus welcome.

Competition also needs to be furthered through political institutions, as the exit option does not suffice to induce governments to act efficiently. The citizens should directly elect the persons managing the FOCJ, and should be given the right to initiate popular referenda on specific issues. These democratic institutions are known to raise efficiency in the sense of meeting individual preferences (on elections, see Downs [1957], Mueller [1989], for referenda Cronin [1989], Frey [1994]).

\subsection{Jurisdictions}

A FOCUS is a democratic governmental unit with authority over its citizens, including the power to tax. According to the two types of overlap, two forms of membership can be distinguished: (i) The lowest political unit (normally the community), and all its corresponding citizens automatically become citizens of the FOCJ to which their community belongs. In that case, an individual can only exit by relocating. (ii) Individuals may freely choose whether they want to belong to a particular FOCUS but, while they are its citizens, they are subject to its authority. Such FOCJ may be non-voluntary in the sense that one must belong to a FOCUS providing for a certain function, e.g., to a school-FOCUS, and must pay the corresponding taxes. An analogy here is health insurance, which in many countries is obligatory, but individuals are free to choose any insurance company. The citizens of such a school-FOCUS may then decide that everyone must pay taxes in order to finance a particular school, irrespective of whether one has children. With respect to FOCJ providing functions with significant redistributive effects, a minimal regulation by the central government may grant that, e.g., citizens without children may abstain from joining 'school-FOCJ', which in effect do not offer any schooling and therefore have correspondingly low (or zero) taxes. 


\section{Strengths of FOCJ}

FOCJ compare favorably to traditional forms of federalism with respect to government incentives and possibilities to satisfy heterogeneous preferences of the individual. Due to the concentration on one functional area, the citizens of a particular FOCUS receive better information on its activity, and are in a better position to compare its performance to other governments. As many benefits and costs extend over a quite limited geographic area, we envisage FOCJ to be small in size, which is also helpful for voters' evaluations. The exit option provided by the existence of overlapping jurisdictions is also an important means to make one's preferences known to governmental suppliers.

Moreover, FOCJ are able to provide public services at low cost, because they are formed in order to minimize inter-jurisdictional spillovers and to exploit economies of scale. When the benefits of a specific activity indivisibly extend over large areas, and when there are decreasing costs, the corresponding optimal FOCUS may cover many communities, several nations, or even Europe as a whole. Defense against aggression from outside may be an example where the appropriate FOCUS may extend over the whole of Europe (even beyond the European Union).

The threat of dissatisfied citizens or communities exiting the FOCUS, and the benefit of new citizens and communities joining, gives the politicians in charge an incentive to take the preferences of the citizens into account and to provide public services efficiently. FOCJ may also open up the politicians' cartel to competent outsiders. While all-purpose jurisdictions attract people with broad and non-specialized knowledge to become politicians, in FOCJ individuals with a well-grounded knowledge in a particular functional area (say education or refuse collection) are successful.

A federal network composed of FOCJ certainly affects the role of the nation-states. They will definitely be relieved of those functions if they do not fulfill them according to the population's preferences, or of those, which they perform at higher cost than FOCJ designed to exploit cost advantages. On the other hand, the scheme 
does not purport to do away with nations, but allows for multi-national, as well as small-scale alternatives where they are so desired by the citizens. Nation-states subsist in so far as they provide functions efficiently according to the voters' preferences.

\section{Claimed Weaknesses of FOCJ}

There are four major criticisms, which could be advanced against the concept of FOCJ.

Citizens are overburdened by the voting load. In a federal system of FOCJ, each individual is a citizen of various jurisdictions. As a consequence, individuals may be overburdened by the voting in elections and referenda that take place in each FOCUS. However, citizens in a direct-democratic FOCUS find it much easier to politically participate, as they have only to assess one or two concrete issues at a time. The referenda and elections in the various FOCJ can be held at the same time, say on three or four dates per year, and the votes can, without any problems, be cast by mail or E-mail.

Citizens are cognitively overburdened. An individual is confronted with a multitude of suppliers of public services, which arguably could make life difficult. However, FOCJ do not cause the dimensionality of politics to grow. Rather, the dimensionality is made explicit. The evidence from private consumer markets shows us that citizens are able to cognitively master an incredibly broad array of matters, if they have the appropriate information. However, FOCJ provide stronger incentives and opportunities for citizens to be politically informed than traditional forms of government do. Membership in FOCJ is decided on a local or even private level, and the performance of functional units can easily be monitored through comparison and benchmarking. If citizens, nevertheless, fear that the appropriate information is lacking, a governmental or a private advisory service can be established, which 
offers information and support for the consumers' needs and wishes.

Coordination is needed. While co-ordination is obviously often needed, coordination between governments is not necessarily beneficial. It sometimes serves to build cartels among the members of the 'classe politique' who then evade or even exploit the population's wishes (see CEPR 1993, Vaubel 1994, Frey 1994). As far as welfare increasing co-ordination is concerned, its need is reduced because the FOCJ emerge in order to minimize externalities. If major spillovers between FOCJ exist, new FOCJ will be founded, so taking care of these externalities.

Income needs to be redistributed. It is sometimes claimed that all forms of federalism - including FOCJ - undermine redistribution. Moreover, FOCJ are claimed to emerge especially in high-income areas. As far as redistribution is based on the citizens' solidarity or on insurance principles, this fear is unwarranted. Only as far as redistribution is indeed a pure public good, and thus must be enforced to prevent free-riding, may a problem arise. But even then, FOCJ compare favorably to traditional forms of federalism; they lead to less geographical segregation because the citizens can select their supplies without relocating. However, recent empirical research (Gold 1991, Kirchgässner and Pommerehne 1996, Ashworth, Heyndels and Smolders 2002) suggests that substantial redistribution is feasible in federal systems. Moreover, to the extent that redistribution is a pure public good, it will be delegated to higher level governments or, perhaps, to specialized redistribution FOCJ at the national or European levels. 


\section{Contemporary Examples of FOCJ}

In two countries, functional, overlapping and competing jurisdictions exist (but they do not in every case meet all the requirements of FOCJ specified above).

In the United States, special districts play a significant role in the American federalist system, and their numbers have substantially increased over the last decades. While some of the special districts are dependent, others are both autonomous and democratically organized. According to empirical research (Mehay [1984]), the latter type is significantly more efficient. Not surprisingly, existing municipalities make an effort to prevent the emergence of these more efficient governmental units. Thus, for example, in various states, a minimum population size is required and various administrative restrictions are imposed.

In Switzerland, a multitude of governmental units exist, some of which resembling FOCJ. In addition to the 26 cantons, there are roughly 8,000 communes of various forms. The most important are the 2,940 political communes, which define citizenship (i.e. a Swiss is not a citizen of the nation but of a political commune). These communes have considerable autonomy; in particular they have wide-ranging authority to impose taxes on income and property. As a consequence, the tax rates between neighboring political communes may differ strongly - a factor inducing political competition between communes, and bundles of public services and taxes, which are favorable to the citizens. In addition to political communes, there are roughly 5,000 overlapping, functional special communes. The most important are school communes offering education to the children of one or several political communes. They are public jurisdictions levying their own taxes, the rates of which are determined at a citizens' meeting. Other functional, democratic, and overlapping communes are those established by the Protestant and Catholic Churches. A citizen may freely choose to which one he or she wishes to belong, but once a member, one has to pay an appropriate tax. In addition to these and other types of communes, there are many thousands of "communal units" ("Gemeindeverbände" or "Zweckverbände") founded by the communes to deal with specific tasks such as, 


\section{A New Concept of European Federalism}

hospitals, nursing homes, maintenance of sewage systems or refuse collection. These units have, however, no independent power to tax and there rarely exist direct participation rights for citizens. This short discussion of the Swiss federal system at the local level (see more extensively De Spindler [1998]) shows that FOCJ are a practical possibility, but that they have not yet been developed to their full extent.

A completely different kind of FOCJ develops in Cyberspace. An example is the Internet Corporation for Assigned Names and Numbers (ICANN), the body that now administers Internet domain names.

It could well evolve into a global regulation institution without any territorial boundaries. While laws that govern business conduct are primarily country-specific, the Internet acknowledges no such geographic borders, and net firms can move from one jurisdiction to another by switching the location of their servers. ICANN is not a governmental institution (though it was initiated by the US government); it is based on openness and collaboration rather than closed procedural regulation. It seeks to establish wider legitimacy by holding democratic elections, relies on voluntary dispute-resolution channels, and adapts its policy to rapidly changing technology. This new kind of Cyberspace body thus has several features of FOCJ: it is functional and overlapping; it allows entry and exit and establishes democratic accountability; and it imposes prices (taxes) for its services. It is much closer to the idea of FOCJ developed here than to traditional forms of government.

\section{Competing Proposals}

FOCJ differ in many crucial respects from other proposals concerning a future European constitution. One of the most prominent proposals is Buchanan's (1991), who stresses an individual nation's right to secede but, somewhat surprisingly, does not build on Buchanan-type clubs. The European Constitutional Group (1993) focuses on the example of the American constitution, and presents constructivist proposals with respect to the houses of parliament and the respective voting weights 
of the various countries. They do not allow for overlapping jurisdictions and referenda, and the exit option is strongly restricted. Other economics scholars (e.g., Blöchliger and R.L. Frey 1992, Schneider 1992) suggest a strengthening of federalism in the traditional sense (i.e. through multi-purpose federal units) but do not envisage overlapping jurisdictions. The report by the Centre for Economic Policy Research (1993, 1995) criticizes "subsidiarity" (as used in the Maastricht Treaty) to be a meaningless concept, as they argue that good theoretical reasons must be provided to justify central government intervention. But the report does not deal with the institutions necessary to guarantee that policy follows such theoretical advice. The idea of overlapping, not geographically based jurisdictions, is briefly raised (1993, pp. 54-55) but is not institutionally or practically worked through, nor is the need for a democratic organization and the power of taxation acknowledged.

The proposal by European level politicians (Herman report of the European Parliament, 1994) mainly deals with the organization of the parliamentary system (the houses of parliament and the national vote weights) and to a substantial extent accepts the existing treatises as the founding blocks of the European constitution. The central idea of competition between governments is neglected; the report prefers to speak of the necessary "co-operation" between governments - which in fact often serves to undermine the threat of competition.

FOCJ are also quite different from the regions envisioned in existing European treaties and institutions (see, e.g., Adonis and Jones 1991). A significant difference is that FOCJ emerge from below, while the 'European regions' tend to be established from above. Moreover, their existence strongly depends on the subsidies flowing from the European Union and the nation states (Sharpe 1993). In contrast, the concept of FOCJ corresponds to Hayek's (1960) non-constructivist process view. It cannot a priori be determined from outside or from above, which FOCJ will be efficient in the future. This must be left to the competitive democratic process that takes place at the level of individuals and communities. The central European constitution needs to make sure that other government units, in particular nation states, do not obstruct the emergence of FOCJ. In contrast to Hayek's proposal, 


\section{A New Concept of European Federalism}

however, the scheme allows for a (closely restricted) set of central regulations, as mentioned above. Moreover, Hayek measures efficiency through survival in the evolutionary process, while efficiency is defined here in terms of the fulfillment of citizens' demands.

"Subsidiarity", as proclaimed in the Maastricht Treaty, is generally perceived to be more of a vague ambition than a concrete concept with substantial content (see, e.g., Centre for Economic Policy Research 1993, pp. 19-23). Even if subsidiarity were taken seriously, it would not lead to a veritable federal structure, because many (actual or prospective) members of the European Union are essentially unitary states without any federal sub-units of significant competence (examples are the Netherlands, France or Sweden). The "regions" existing in the European Union (examples are Galicia and Cataluña in Spain, or South Tyrol and Sicily in Italy) are far from being units with significant autonomous functional and fiscal competencies.

The Council of Ministers is a European decision making institution based on federal principles (but only nations are represented) and organized according to functional principles (or at least according to the corresponding administrative units). However, this Council is only indirectly democratic (the ministers are members of governments, which are democratically legitimized by the representative system) and the deliberations are not public. Exit from the European Union is not formally regulated, and exceptions to specific aspects of agreements reached (as in the Maastricht Treaty concerning the European Monetary Union and the Protocol on Social Policy, or in the Schengen Treaty concerning the free movement of persons) are granted only reluctantly. Indeed, they are seen as damaging the "spirit of Europe". 


\section{Conclusion: FOCJ and the European Union}

Functional, Overlapping and Competing Jurisdictions may be considered a most useful concept for the European Union. This flexible set of institutions allows its citizens to have their divergent preferences fulfilled better than under the present inflexible institutional arrangements. The size of governmental units adjusts to the problems to be solved rather than being determined by historical flukes. To some extent the European Union already faces the problem that its present type of federalism is ill suited for the problems at hand. This is most obvious when it comes to the integration of additional countries into the Union. The case of Turkey is especially relevant. In several countries of the European Union many voters seem to think that some of the religious and political features of Turkey do not fit well into the Union, and some even fear that an entry would jeopardize basic human rights. Accordingly, some governments of EU member countries are reluctant to support the membership of Turkey, or even oppose it. A flexible integration via FOCJ would provide a way out without any side losing face. Turkey could immediately become a member with respect to those functions with little or no opposition, such as free trade in goods and services. Such a FOCUS would undoubtedly be beneficial for both the European Union and Turkey, and should therefore not be delayed. There are certainly many other areas, or functions, for which Turkey could easily be admitted into the Union. In contrast, a political union with Turkey does not find a consensus among the present member countries, nor does a free movement of labor. Within the flexible concept of FOCJ these issues can be delayed without harming progress in other areas. It would, moreover, allow Turkey, and the European Union, to extend beyond its present geographical boundaries. Thus, for instance, a full free trade arrangement with Turkey could also include the Maghreb countries as well as Eastern European countries such as the Ukraine and Georgia. At the same time, those member states of the European Union, which do not agree to such FOCJ, do not have to participate. In that way, these countries become more closely associated with those West European countries willing to cooperate. Such a move can be expected to contribute to not only the economic, but also to the political development towards 


\section{A New Concept of European Federalism}

democracy and the rule of law in countries presently excluded from the European Union. Democratic and market orientated countries like Norway, Switzerland and Iceland which do not wish to participate in all the treaties binding the present members of the Union, could participate in some of them. Such FOCJ would be beneficial for both sides.

The idea of establishing a multitude of FOCJ connected with countries of the European Union will certainly evoke fierce opposition from many quarters. Many adherents of European integration will argue that such "partial" integration undermines the idea of "unity" among the Europeans. This argument disregards that the strength of Europe lies in its diversity, and that imposing equal rules and standards all over Europe stands against this spirit. But the history of the European integration shows that partial integration has been the only possibility to safeguard the integration process. This has been made most obvious when several member countries refused to join the Euro-zone. From the point of view of flexible integration proposed here, the models of "variable geometry", "multi-track", "multi-speed", "two-tier", "hard core", "concentric circles", or "Europe à la carte" should be welcomed, rather than rejected. But it should be kept in mind that the concept of FOCJ sketched here differs from the models that have just been mentioned in several respects. FOCJ emerge from below when the citizens and the politicians representing them become aware that a particular function can no longer be profitably performed in isolation and that it is, therefore, beneficial to establish new democratic governmental structures with taxing authority. With respect to such a particular function, the integration is based on the consensus of all participants. The situation is not characterized by a well-established center (in the case of the European Union the Commission, the Parliament and the Courts) but by democratic actors of all levels (including regions and communes) jointly undertaking a public task, and taxing the citizens accordingly.

The organization of states today does not follow the model of FOCJ for two major reasons. An obvious, but decisive one, is that individuals and communities are prohibited from establishing such jurisdictions, and in many countries of the 
Bruno S. Frey

European Union, communities are not even allowed to formally collaborate without the consent of the central government (see Sharpe [1993]). Secondly, FOCJ violate the interests of politicians and public officials at higher levels of government. FOCJ reduce the public suppliers' power and increases citizens' influence by the newly introduced mechanisms of competition by entry and exit, and by direct democratic elements; both are regularly opposed by the politicians in power.

A federal system of FOCJ will not arise if these barriers are not overcome. A necessary condition is new constitutional rules, allowing the formation of FOCJ and giving citizens and governments the right to appeal to the Constitutional Court if they are blocked. 


\section{References}

Adonis, A. and St. Jones (1991). 'Subsidiarity and the European Community's constitutional future' Staatswissenschaft und Staatspraxis, 2, pp. 179-196.

Ashworth, J., B. Heyndels and C. Smolders (2002). 'Redistribution as a local public good: an empirical test for Flemish municipalities'. Kyklos, 55 (1), pp. 27-56.

Bird, R. M. (1993). 'Threading the Fiscal Labyrinth: Some Issues in Fiscal Decentralization'. National Tax Journal, 46, pp. 201-221.

Blöchliger, H. and R. L. Frey (1992). 'Der schweizerische Föderalismus: Ein Modell für den institutionellen Aufbau der Europäischen Union?'. Aussenwirtschaft, 47, pp. 515-548.

Buchanan, J. M. (1965). 'An Economic Theory of Clubs'. Economica, 32, pp. 1-14.

Buchanan, J. M. (1991). 'An American perspective on Europe's constitutional opportunity'. Cato Journal, 10, pp. 619-629.

Centre for Economic Policy Research [CEPR] (1993). Making Sense of Subsidiarity: How Much Centralization for Europe? London: CEPR.

Centre for Economic Policy Research [CEPR] (1995). Flexible Integration. Towards a More Effective and Democratic Europe. London: CEPR.

Cronin, T. E. (1989). Direct Democracy. The Politics of Initiative, Referendum and Recall. Cambridge, MA: Harvard University Press.

De Spindler, J. (1998). FOCJ. Ein Konzept zur Neuordnung der Zusammenarbeit öffentlicher Gebietskörperschaften. Bern: Haupt.

Downs, A. (1957). An Economic Theory of Democracy. New York: Harper and Row.

Engel, C. (1999). The Internet and the Nation State. Jena: Lectiones Jenenses, Max-Planck-Institute for Research into Economic Systems.

Frey, B. S. (1994). 'Direct Democracy: Politico-Economic Lessons from Swiss Experience'. American Economic Review, 84, pp. 338-348.

Frey, B. S. (1997). 'The Public Choice of International Organizations'. in: D.C. Mueller (ed.) Perspectives on Public Choice: A Handbook. Cambridge: Cambridge University Press, pp. 106123.

Gold, S. D. (1991). 'Interstate Competition and State Personal Income-Tax Policy in the 1980s'. in: D. A. Kenyon and J. Kincaid (eds.) Competition among States and Local Governments. Washington DC: Urban Institute Press, pp. 205-217.

Hayek, F. A. von (1960). The Constitution of Liberty. London: Routledge.

Hayek, F. A. von (1978). 'Competition as Discovery Procedure'. in: F. A. Hayek (ed.) New Studies in Philosophy, Politics, Economics and the History of Ideas. London: Routledge and Kegan, pp. 119130.

Herman, F. (1994). 'Zweiter Bericht des institutionellen Ausschusses über die Verfassung der Europäischen Union.'. Europäisches Parlament, Sitzungsdokumente (A3-0064/94).

Hirschman, A. O. (1970). Exit, Voice and Loyalty. Cambridge, MA: Harvard University Press. 
Hirschman, A. O. (1993). 'Exit, Voice, and the Fate of the German Democratic Republic'. World Politics, 45, pp. 173-202.

Inman, R. P. and D. Rubinfeld (1997). 'The Political Economy of Federalism'. in: D. C. Mueller (ed.) Perspectives on Public Choice: A Handbook. Cambridge: Cambridge University Press, pp. 73105.

Kirchgässner, G. and W. W. Pommerehne (1996). 'Tax Harmonization and Tax Competition in the European Community: Lessons from Switzerland'. Journal of Public Economics, 60, pp. 351371.

Mehay, S. L. (1984). 'The Effect of Governmental Structure on Special District Expenditures'. Public Choice, 444, pp. 339-348.

Mueller, D. C. (1989). Public Choice II. Cambridge: Cambridge University Press.

Oates, W. E. (1972). Fiscal Federalism. New York: Harcourt Brace Jovanovich.

Oates, W. E. (ed.) (1977). The Political Economy of Fiscal Federalism. Lexington, MA: Lexington Books.

Oates, W. E. (1999). 'An Essay on Fiscal Federalism'. Journal of Economic Perspectives, 37, pp. 1120-49.

Olson, M. 91969). 'The Principle of "Fiscal Equivalence": The Division of Responsibilities among Different Levels of Government'. American Economic Review, 59, pp. 479-487.

Olson, M. (1986). 'Towards a More General Theory of Governmental Structure'. American Economic, Papers and Proceedings, 76, pp. 120-125.

Schneider, F. (1992). 'The federal and fiscal structures of representative and direct democracies as models for a European federal union: Some ideas using the public choice approach.'. Journal des Economistes et des Etudes Humaines, 3, pp. 403-437.

Sharpe, L. J. (ed.) (1993). The Rise of Modern Government in Europe. London: Sage.

Singer, J.D. and M. Small (1982). Resort to Arms: International and Civil War, 1816-1980. Beverly Hills, CA: Sage.

Smith, A. (1776). An Inquiry into the Nature and Causes of the Wealth of Nations. Reprinted 1980, London: Deut \& Sane Ltd..

Tiebout, C. M. (1956). 'A Pure Theory of Local Expenditure'. Journal of Political Economy, 64, pp. 416-424.

Vaubel, R. (1994). 'The Political Economy of Centralization and the European Community'. Public Choice, 81, pp. 151-190. 


\section{Recent LEQS papers}

Jones, Erik. 'They Have No Idea... Decision-making and Policy Change in the Global Financial Crisis'. LEQS Paper No. 4, May 2009

Frey, Bruno. 'A New Concept of European Federalism'. LEQS Paper No. 3, May 2009

Chalmers, Damian. 'Gauging the Cumbersomeness of EU Law'. LEQS Paper No. 2, May 2009

Bellamy, Richard. 'The Liberty of the Post-Moderns? Market and Civic Freedom within the EU'. LEQS Paper No. 1, May 2009 
Eqs 
LEQS

European Institute London School of Economics Houghton Street

WC2A 2AE London

Email: euroinst.LEQS@lse.ac.uk

http://www2.lse.ac.uk/europeanInstitute/LEQS/Home.aspx 